\title{
RURAL TOURISM: THE CONTENT, FEATURES AND TYPES
}

\begin{abstract}
Despite the active development of rural tourism in Ukraine, this phenomenon is still under scientific study nowadays, which has been manifested by the uncertainty of the key terms; by the lack of clear boundaries, which can separate this type of tourism from other types of tourism activities; by debates about the essence and types of rural tourism. After analyzing the available information the author offers own generalized definition of rural tourism. Rural tourism is a specific entertaining and educational type of tourism, which is based on the tourists' stay within rural estates, for the purpose of studying the life of peasants, acquaintance with traditional crafts, culture and customs of the rural population, knowledge of the natural, historical and cultural sites in and around rural settlements.

Spatially this type of tourism is limited to the territory of rural settlements, their surroundings, adjacent areas and lands which are used or were used in agricultural production in the recent past. Rural tourism includes various types of tourist-recreational activities - relaxational and cognitive, nature-oriented and those using historical-cultural and industrial resources of the countryside. Rural tourism is a multifaceted phenomenon which can be viewed from different angles: as a specific type of tourist-recreational activities that takes place in rural areas; as a form of private entrepreneurship in rural areas which can become a source of significant financial income of peasant families and local budgets under certain conditions; as a way of maintaining sustainable development of rural areas through effective, balanced use of natural, historical-cultural and human resources, the preservation and promotion of ethniccultural identity of the peasantry, protection and perception of the environment.
\end{abstract}

Keywords: rural tourism, agrotourism, green tourism, ethnic tourism, ecotourism, sustainable development of rural territories.

\section{Юрій Онойко. СІЛЬСЬКИЙ ТУРИЗМ: ЗМІСТ, ОСОБЛИВОСТІ ТА ФОРМИ}

У статті всебічно проаналізовано сутність такого специфічного соціально-економічного явища як сільський туризм, зокрема наведені авторські трактування ключових термінів згідно предметно-сутнісного підходу, визначені його характерні риси і особливості, які відрізняють даний вид туристської діяльності від інших, розкриті основні організаційнотериторіальні форми, наголошено на значущості сільського туризму для сталого розвитку сільських територій.

Ключові слова: сільський туризм, агротуризм, зелений туризм, етнічний туризм, екологічний туризм, сталий розвиток сільських територій.

\section{Юрий ОНойко. СЕЛЬСКИЙ ТУРИЗМ: СОДЕРЖАНИЕ, ОСОБЕННОСТИ И ФОРМЫ}

В статье всесторонне проанализирована сущность такого специфического социально-экономического явления как сельский туризм, в частности приведены авторские трактовки ключевых терминов согласно предметно-сущностного подхода, определены его характерные черты и особенности, которые отличают данный вид туристической деятельности от других, раскрыты основные организационно-территориальные формы, отмечена значимость сельского туризма для устойчивого развития сельских территорий.

Ключевые слова: сельский туризм, агротуризм, зеленый туризм, этнический туризм, экологический туризм, устойчивое развитие сельских территорий.

Defining of the problem. Despite the fact that agricultural industry belongs to the flagships of the economy, the rural population of Ukraine exists in difficult socio-economic conditions nowadays which causes the intense depopulation of rural settlements as a result of natural causes as the residents leaving for the cities.

But despite this, rural areas in Ukraine are characterized: by the presence of many interesting natural and historical-cultural objects; by comfortable enough conditions to live in a natural environment; by unique culture and traditions; by a significant amount of uninvolved labour resources that can be used in the process of organization of tourist-recreational activities on their territory. Besides, a sustained interest for relaxation within recreations, which are remote from city bustle, ecologically clean areas with minimal human impact on the environment has been observed from inhabitants of large cities. These tendencies have caused formation of such a direction of tourism as rural in Ukraine.

However, despite the active development of rural tourism in Ukraine, this phenomenon is still under scientific study nowadays, which has been manifested by the uncertainty of the key terms; by the lack of clear bounda- ries, which can separate this type of tourism from other types of tourism activities; by the debates about the essence and types of rural tourism.

The analysis of the last researches and publications. The essence, organizational forms and spatial features of rural tourism development in Ukraine were studied by V.V. Glovatska (Dnipropetrovs'k, 2006), T.Yu. Luzhanska, S.S. Makhlynets and L.I. Teblyashkina (Kyiv, 2008), M.Y. Rutynskyi and Yu.V.Zin'ko (Kyiv, 2008), M.M. Pityulych and I.I. Mykhailyuk (Uzhgorod, 2011), O.V. Vynogradova and V.G. Darchuk (Donetsk, 2013), O.B. Burova (Kyiv, 2013), N.Ye. Kudla (Kyiv, 2015), Yu.Yu. Onoyko and V.S. Krolik (Kiev, 2012; Kharkiv, 2014; Kropyvnytskyi, 2017) and others.

The purpose of writing the article. The purposes of writing this article are to find out the essence and specific features of rural tourism as a separate type of tourism activities; to offer a clear definition of the key concepts on the basis of the analysis of sources and personal reflections; to reveal the importance of rural tourism for the sustainable development of rural areas. 
The main material of the article. The unambiguous interpretation of the key terms is the guarantee of the effective scientific discussion. The concept of "rural tourism" is the basic concept of this publication, the content of which, at first sight, seems to be quite clear - the type of tourist activity which is carried out in a rural location. However, after analyzing various sources of information we can conclude that clear generally accepted interpretation of this term does not exist in modern tourismology. The definitions of rural tourism that were given by separate authors either substantially differentiate from one another or they are rather formal and do not reveal the specifics of rural tourism. Quite often the concept of "rural tourism" is identified and replaced by other concepts: "ecotourism", "green tourism", "agrotourism", "farm tourism", "country tourism" and some other.

The need of solving such problems was highlighted in the "Project ... on introduction of amendments to the Law of Ukraine "On personal peasant farm" about the development of green tourism (from 02.07.2015) [7]. Particularly, the Project provided that it was advisable to fix the definition of the relevant concepts on the legislative level for proper legislative development of rural tourism in our country. In our opinion, a broad discussion on the conceptual foundations of this type of tourism, including terminology should be preceded by all aforesaid.

The concept "rural tourism" was not mentioned in one of the first dictionaries of geography of tourism and recrealogy in Ukraine (by O.O. Beydyk, 1993 [2]; 1998 [1]) although the content of such original types of tourism as gynecological and sex tours had been revealed in details. It is possible to make the assumption that the absence of this notion in gazetteers was caused by the low level of rural tourism development in Ukraine (particularly in the early 90 -ies of the XX century); by the lack of scientific understanding and the traditional utilitarian approach to the perception of agriculture as a food producer, but not a potential object of tourism activities. However, the concept of "ecotourism", the content of which was not completely correlated with the "rural tourism», had been pointed out in the dictionaryreference book of O.O. Beydyk (1998) [1]". The author of the dictionary understands the ecological tourism as the visits to the protected areas with the purpose of acquaintance with nature, methods and forms of environmental protection with the minimal tourist impact on the environment.

American and Western European scientists had developed somewhat broader understanding of ecological tourism. So the Union of ecotourism of the USA [11] formulates the following definition: "ecological tourism are the travels to the places with the untouched nature, which do not lead to violation of the integrity of ecosystems; are conducted with the aim of gaining an understanding about natural, cultural-ethnographic features of this territory; the creation of very specific economic conditions, in which the nature conservation becomes profitable to the local population, are realized". Rural tourism answers the criteria of ecological tourism in compliance with this formulation.
According to the Oxford dictionary of tourism and hotel business (in the original language - Dictionary of Travel, Tourism and Hospitality), edited by S. Medlik [11], "rural tourism is a type of relaxational tourism focused on the rural areas, which envisages the development of tourist routes, places for recreation, agricultural and folk museums as well as centers for tourists...".

But let us turn to the works of the specialists, who have studied rural tourism in Ukraine. We agree with these scientists $[3 ; 4 ; 9]$, that the concepts of "rural tourism", "ecological tourism" and "agrotourism" are not completely identical and must be clearly delineated, although close to each other. The broadest among these is the concept of "ecological tourism", which covers all types of tourism activities within the little-changed human territories and provides a balanced use of their natural and historical-cultural resources for sustainable development of the regions (S. Novytska, 2013 [5]). Thus, rural tourism can be considered as a kind of environmental one. To emphasize the orientation of rural tourism in the areas with little anthropogenic influence, the characteristic "green" has been used. The notion "rural green tourism" now appears frequently in scientificpopular literature, primarily to determine its natureoriented components.

It can be mostly understood as the agrotourism, (T.Y. Luzhanska, 2008 [4]) a tourist activity that is concentrated in rural areas and involves using of rural households for recreation, attracting tourists to traditional forms of management, analyzing the processes of agricultural industry and customs of a particular region. Agrotourism can take many forms, but it always includes the provision of services to tourists visiting a rural estate. Therefore, the concept of "rural tourism" is much broader than the concept of "agrotourism". Those types of tourism activities in rural areas, which are not related to agricultural industrial activities, cannot be carried out according to this determination of agrotourism. Agrotourism, country, green, ethnic, farm types of tourism are often considered by experts $[4 ; 9]$ as separate forms (types) of the organization of rural tourism, which differ in the main purpose of stay and resource base.

Thus, after analyzing the available information, we can propose our own definition of rural tourism. Rural tourism is a specific entertaining and educational type of tourism, which is based on the stay of tourists within the rural estates, with the aim of studying the life of peasants, acquaintance with traditional crafts, culture and customs of the rural population, knowledge of the natural, historical-cultural sites in and around rural settlements (Yu.Yu. Onoyko, V.S. Krolik, 2012 [6; 7]). This definition highlights the specific features of rural tourism, which constitute its essence and distinguish it from other types of tourist activities.

1. Spatially, rural tourism is limited by the territory of rural settlements, their surroundings, the surrounding areas and lands that are used or were used in agricultural production in the recent past. This approach allows separating more clearly rural tourism from urban and suburban types of tourism, and those types of ecological tourism, which are concentrated on the territories which are far away from any settlements. 
2. Rural tourism includes different types of tourism and recreational activities: entertaining and informative, nature-oriented and those that use historical-cultural and production resources of rural areas.

Nature-oriented forms of rural tourism have been described by the definition of "rural green tourism". Agrotourism is based primarily on using of the productive resources of households, but the historical-cultural resources of rural areas are the ethnic base of rural tourism. Farm and country tourism belong to the varieties of agrotourism. Farm tourism includes a visit to the agricultural farm with animals, where tourists watch the animals, have fun and take care of them. A visit to the horse farm with services such as horseback riding can be a good example of farm tourism. Country tourism is presented by having a rest on the basis of own private housing stock in the countryside (T.Yu. Luzhanska, 2008 [4]).

3. Rural lifestyle, traditions and crafts of rural residents, their agricultural activities, festivals, traditional rural buildings, rural estates, museums, historical, cultural and natural sites (mostly biotic and water) rural areas are the most important attractions of rural tourism.

4. The rural households (green manor, a hospitable mansion, eco-estate, agro-estate, farmsteads), which on the one hand are the place of stay and overnight stays, and on the other - specific tourist attraction, are most frequently considered as the basis for the organization and conducting of rural tourism.

5. A key role in the organization of rural tourism has been carried out by the rural residents (farmers) in rural areas. They provide their homes and farms to the needs of tourists, develop tourist routes and excursions, trips and cultural programs, act as guides, maintain the natural, historical-cultural tourist attractions in good conditions, provide transportation and meals for tourists, rent of tourist equipment, produce and sell souvenirs for tourists. Besides the everyday life, customs and production activities of peasants are also the main baitattraction of rural tourism.

6. Rural tourism can be considered from different perspectives: as a specific type of tourism and recreational activities that is provided in rural location; as a form of private entrepreneurship in rural areas, which becomes a source of significant financial income of peasant families and local budgets under certain conditions; as a means of maintaining sustainable development of rural areas through the effective usage of natural, historical-cultural and human resources, preservation and promotion of ethnic-cultural identity of the peasantry, protection and knowledge of the environment. The diversity of rural tourism and its socio-economic importance for rural areas and their inhabitants follows from these positions.

Conclusions. Therefore, rural tourism in Ukraine requires proper attention from the authorities, local communities, businesses, and academia as one of the main ways of ensuring sustainable development of rural territories, a promising direction for effective solutions to a number of socio-economic problems of the rural population and the need to preserve natural, historicalcultural heritage of the Ukrainian village. There are actual problems of the improvement of theoreticmethodological and normative-legal frameworks of rural tourism development, in particular the comprehensive scientific study of the phenomenon, establishing definitions of the key terms, a clear delineation of rural tourism from related species, understanding of its nature, capabilities, strengths and weaknesses, public discussion and approval of corresponding normative-legal acts remain before scientists for today.

\section{Список використаних джерел:}

1. Бейдик О.О. Словник-довідник з географії туризму, рекреалогії та рекреаційної географії / О.О. Бейдик. К.: Палітра, 1998. - 130 с.

2. Бейдик О.О. Тлумачний словник термінів з рекреаційної географії (географії туризму) / О.О. Бейдик. - К.: Київський університет, 1993. - 56 с.

3. Кудла Н.С. Сільський туризм: основи підприємництва та гостинності / Н.Є. Кудла. - К.: Центр учбової літератури, 2015. - 152 с.

4. Лужанська Т.Ю. Сільський туризм: історія, сьогодення та перспективи / Т.Ю. Лужанська, С.С. Махлинець, Л.І. Тебляшкіна. - К.: Кондор, 2008. - 385 с.

5. Новицька С. Екологічний туризм як пріоритетний напрямок сталого розвитку туристичної сфери / С. Новицька // Наукові записки Тернопільського національного педагогічного університету імені Володимира Гнатюка. Серія: Географія. - Тернопіль, 2013. - № 2. - С. 164-169.

6. Онойко Ю.Ю. Організаційно-територіальна структура, проблеми та перспективи розвитку сільського зеленого туризму на теренах Кіровоградської області / Ю.Ю. Онойко, В.С. Кролік // Регіон-2014: суспільногеографічні аспекти: Матеріали міжнародної науково-практичної конференції. - Харків: ХНУ ім. В.Н. Каразіна, 2014. - С. 235-238.

7. Онойко Ю.Ю. Сучасний стан, умови, проблеми та перспективи розвитку сільського зеленого туризму в Кіровоградській області / Ю.Ю. Онойко, В.С. Кролік // Туризм сільський зелений. - Випуск 2. - Київ, 2012. - С. 20-23.

8. Проект Закону про внесення змін до Закону України «Про особисте селянське господарство» щодо розвитку сільського зеленого туризму за № 2232а від 02.07.2015 р. [Електронний ресурс] // Офіційний веб-портал Верховної Ради України. - Режим доступу: www.rada.gov.ua

9. Рутинський М.Й. Зелений туризм / М.Й. Рутинський, Ю.В. Зінько. - К.: Знання, 2008. - 271 с.

10. Словник рекреаційних термінів / укладач С.С. Бєляєва. - К.: ВЦ «Академія», 2011. - 184 с.

11. Medlik S. Dictionary of Travel, Tourism and Hospitality / S. Medlik. - 3-d ed. - Elsevier Science, 2003. - 288 p.

12. Weaver D. Ecotourism / Weaver David. - N.-Y.: John Wiley \& Sons, Inc, 2002. - 400 p. 


\section{References:}

1. Beydyk, O.O. (1998). Slovnyk-dovidnyk z geografii turyzmu, rekrealogii ta rekreatsiynoi geografii [The Dictionary-Reference in Geography of Tourism, a Recrealogy and Recreational Geography]. Kyiv, Ukraina: Palitra [in Ukrainian].

2. Beydyk, O.O. (1993). Tlumachnyi slovnyk terminiv z rekreatsiynoi geografii (geografii turyzmu) [The Explanatory Dictionary of Terms on Recreational Geography (Tourism Geography)]. Kyiv, Ukraina: Kyivskyi universytet [in Ukrainian].

3. Kudla, N.Ye. (2015). Silskyi turyzm: osnovy pidpryiemnytstva ta hostynnosti [Rural Tourism: the Foundations of Entrepreneurship and Hospitality]. Kyiv, Ukraina: Tsentr uchbovoi literatury [in Ukrainian].

4. Luzhanska, T.Yu., Makhlynets, S.S., Teblyashkina, L.I. (2008). Silskyi turyzm: istoriya, sohodennia ta perspektyvy [Rural Tourism: History, Modernity and Prospects]. Kyiv, Ukraina: Kondor [in Ukrainian].

5. Novytska, S. (2013). Ekologichnyi turyzm yak priorytetnyi napriamok staloho rozvytku turystychnoi sfery [Ecological Tourism as Priority Direction of Sustainable Development of the Tourist Sphere]. Naukovi zapysky Ternopilskoho natsionalnoho pedagogichnoho universytetu imeni Volodymyra Hnatyuka. Seriya: Geografiya, 2, 164-169 [in Ukrainian].

6. Onoyko, Yu.Yu., Krolik, V.S. (2014). Organizatsiyno-terytorialna struktura, problemy ta perspektyvy rozvytku silskoho zelenoho turyzmu na terenakh Kirovohradskoi oblasti [Organizational and Territorial Structure, Problems and Prospects of Development of Rural Green Tourism in the Territory of Kirovohrad Region]. Region-2014: suspilno-geohrafichni aspekty. Kharkiv: KhNU im. V.N. Karazina, 235-238 [in Ukrainian].

7. Onoiko, Yu.Yu, Krolik, V.S. (2012). Suchasnyi stan, umovy, problemy ta perspektyvy rozvytku silskoho zelenoho turyzmu v Kirovohradskii oblasti [The Current State, Conditions, Problems and Prospects of Development of Rural Green Tourism in the Kirovograd Region]. Turyzm silskyi zelenyi, 2, 20-23 [in Ukrainian].

8. Proekt Zakonu «Pro vnesennya zmin do Zakonu Ukrainy «Pro osobyste selyanske hospodarstvo» shchodo rozvytku silskoho zelenoho turyzmu» [The Bill on Introduction of Amendments to the Law of Ukraine "On Personal Peasant Farm" on Development of Rural Green Tourism at No. 2232 from 7/2/2015.] (2015). Available at: www.rada.gov.ua. [in Ukrainian].

9. Rutynskyi, M.I., Zinko, Yu.V. Zelenyi turyzm [Green Tourism] (2008). Kyiv, Ukraina: Znannia [in Ukrainian].

10. Belyaeva, S.S. (Ed.). (2011). Slovnyk rekreatsiynykh terminiv [Dictionary of Recreational Terms]. Kyiv, Ukraina: VTs «Akademiya» [in Ukrainian].

11. Medlik, S. (Ed.). (2003). Dictionary of Travel, Tourism and Hospitality. 3-d ed. Oxford, Elsevier Science [in English].

12. Weaver, D. (Ed.). (2002). Ecotourism. N.-Y.: John Wiley \& Sons, Inc. [in English]. 